\title{
Contribution of the Knowledge of the Families Acrididae and Gryllidae (Orthoptera: Insecta) of Harput Region (Elazı ̌̆/Turkey)
}

\author{
İnanç ÖZGEN' ${ }^{1}$ Evgeniy TERSKOV², Akın TEMIZZER ${ }^{3}$
}

ÖZET: In this study, Orthoptera fauna of Elazı $\breve{g}$ (Harput) was investigated. In Harput, 7 species/subspecies were determined. These species: Dociostaurus (Stauronotulus) hauensteini (Bolívar,1893), Stenobothrus zubowskyi (Bolívar, 1899), Chorthippus mollis mollis (Charpentier, 1825), Dociostaurus (Stauronotulus) hauensteini (Bolívar,1893), Ramburiella turcomana (Fischer von Waldheim, 1846), Pyrgodera armata (Fischer von Waldheim, 1846) and Gryllus campestris (Linné, 1758). G. campestris (Linné, 1758) and S. zubowskyi (Bolívar, 1899) was firstly recorded in Elazığ fauna.

Key words: Elazığ, fauna, Orthoptera, Turkey

\section{Harput (Elazığ/Türkiye) Bölgesi Acrididae ve Gryllidae Familyaları (Orthoptera: Insecta) Bilgisine Katkılar}

ÖZET: Bu çalışma; Elazığ ili Harput bölgesi Orthoptera faunasının belirlenmesi amacıyla yürütülmüştür. Çalışma sonucunda, 7 adet tür/alt tür belirlenmiştir. Bu türler; Dociostaurus (Stauronotulus) hauensteini (Bolívar, 1893), Stenobothrus zubowskyi (Bolívar, 1899), Chorthippus mollis mollis (Charpentier, 1825), Dociostaurus (Stauronotulus) hauensteini (Bolívar, 1893), Ramburiella turcomana (Fischer von Waldheim, 1846), Pyrgodera armata (Fischer von Waldheim, 1846), Gryllus campestris (Linné, 1758)'dir. Gryllus campestris (Linné, 1758) ve S. zubowskyi (Bolívar, 1899), Elazığ ili faunası için ilk kayıttır.

Anahtar Kelimeler: Elazı̆̆, fauna, Orthoptera, Türkiye

Fırat Üniversitesi, Baskil Meslek Yüksekokulu, Baskil Meslek Yüksekokulu, Elazığ, Türkiye

Institute of Arid Zones, Southern Scientific Center (RAS), Southern Scientific Center (RAS), Rostov on Don, Rusya Federasyonu

Fırat Üniversitesi, Biyoloji Bölümü, Biyoloji Bölümü, Elazığ, Türkiye

Sorumlu yazar/Corresponding Author: İnanç ÖZGEN, inancozgen@gmail.com 


\section{INTRODUCTION}

The territory of Turkey is characterized by a wide range of different landscapes. At present, 682 species and subspecies of Orthoptera are described from Turkey (Anonymous, 2016); still this number continues to increase every year. Nevertheless, many cites remain unknown.

\section{MATERIAL and METHOD}

This study was carried out from the mid March to the mid September between 2013 to 2014 years in Harput Area (Elazığ province). The specimens were collected by sweep net. They are determined by second author. Specimens were preserved to dry material. The material is deposited in the private collections of first and second authors.

\section{RESULTS and DISCUSSION}

Species: Dociostaurus (Stauronotulus) hauensteini (Bolívar, 1893)

Distribution in Turkey: Elazı $\breve{g}$, Erzincan and Malatya (Erman and Salman, 1990; Çıplak et al., 1999; Sevgili et. al., 2012)

Material examined: Elazığ, 2 exs., Harput, Obuz, 13.VII.2013, leg. Özgen

Species: Stenobothrus zubowskyi (Bolívar, 1899)

Distribution in Turkey: Çorum, Muş, Tokat (Önder et. al., 1999)

Material examined: Elazığ, 3 exs., Harput, Obuz, 07.VIII.2014, leg. Özgen

Species: Chorthippus (Glyptobothrus) mollis mollis (Charpentier, 1825)

Distribution in Turkey: Ardahan, Amasya, Elazı ğ, Erzincan, Erzurum, Giresun, Gümüşhane , Kastamonu, Rize, Samsun and Sivas (Erman and Salman; 1990; Çıplak et al., 1999).

Material examined: Elazığ, 3 exs., Harput, Obuz, 07.VII.2014, leg. Özgen.

Species: Dociostaurus (Stauronotulus) hauensteini (Bolívar, 1893)

Distributionin Turkey : Bayburt, Şanlıurfa (Sevgili and Çıplak, 2000), Bayburt (Mol and Zeybekoğlu, 2013).

Material examined: Elazığ, 2 exs., Harput, Obuz, 07.VII.2013, leg. Özgen.

Species: Ramburiella turcomana (Fischer von Waldheim, 1846)
Distribution in Turkey: It is known from whole of Turkey, but it is possibly absent from Karadeniz region, Erzincan: Kemaliye, (Sevgili et al., 2012).

Material examined: Elazığ, 4 exs., Harput, Obuz, 11.VII.2013, leg. Özgen.

Species: Pyrgodera armata (Fischer von Waldheim, 1846)

Distribution in Turkey: Malatya and Elazı $\breve{g}$, Erzincan (Kemaliye district) (Erman and Salman, 1990; Çıplak et al., 1999; Sevgili et al., 2012)

Material examined: Elazığ, 2 exs.,Harput, Obuz, 03.VII.2013, leg. Özgen

Species: Gryllus campestris (Linné, 1758)

Distribution in Turkey: It is known from whole of Turkey (Sevgili et al., 2012).

Material examined: Elazığ, 2 exs., Harput, Obuz, 03.VII.2013, leg. Özgen.

\section{CONCLUSION}

A total of seven species of Orthoptera belonging to families Acrididae and Gryllidae were recorded. Three of them, namely C. mollis, R. turcomana, G. campestris, are widespread. G. campestris (Linné, 1758) and S. zubowskyi (Bolívar, 1899) was firstly determined in Elazığ fauna.

\section{REFERENCES}

Anonymous, 2016. Turkish Orthoptera Site. http://www.orthoptera-tr.org/index.php/check-list-of-the-turkish-orthoptera. Access Date. (01.03.2016).

Çıplak B, Demirsoy A, Bozcuk AN, 1996. Malatya ve civarı Caelifera (Orthoptera, Insecta) faunas1. Turk. J. Zool. 20: 17-31.

Erman O, Salman S, 1990. Elazığ ili Orthoptera (Insecta) faunasi. X. Ulusal Biyoloji Kongresi, 18-20 Temmuz, Erzurum.

Önder F, Pehlivan E, Karsavuran Y, Tezcan S, Kısmalı Ş, 1999. Catalogue of the Collection of Pamphagidae, Pyrgomorphidae, Catantopidae and Acrididae (Orthoptera: Acridoidea) preserved in the Prof Dr. Niyazi Lodos Museum, İzmir, Turkey. Türk.entomol. Derg.,23 (3): 163-178.

Mol A, Zeybekoğlu Ü, 2013. Distribution and Taxonomy of Gomphocerinae (Orthoptera: Acrididae) Species in the Anatolian Black Sea Basin and Check List of Turkey Subfamily Fauna. J. Entomol Res. Soc., 15 (2): 69-102.

Sevgili H, Çiplak B, 2000. The Orthoptera of Şanlıurfa province from the Mesopotomian part of the Turkey. Italian Journal of Zoology, 67: 229-240.

Sevgili H, Demirsoy A, Durmuş Y, 2012. Orthoptera fauna of Kemaliye (Erzincan). Hacettepe J. Biol.\&Chem., 317-335. 